DOI: 10.2478/v10289-012-0021-y

Vol. 56 No. 22012

Journal of Apicultural Science

VERSITA

\title{
FLOWER PREFERENCES OF THE WROCLAW BOTANICAL GARDEN BUMBLEBEES (Bombus spp.)
}

\author{
Aneta Sikora, Maria Kelm \\ Wrocław University of Environmental and Life Science, \\ Faculty of Plant Protection, pl. Grunwaldzki 24a, \\ PL - 50-363 Wroclaw \\ e-mail: aneta.sikora.up@gmail.com
}

Received 28 March 2012; accepted 21 September 2012

\section{$\mathrm{S}$ u m m a r y}

Bumblebees (Bombus spp.) are morphologically different from each other as determined by the length of their tongue. Seven species of bumblebees were identified in the Wrockaw Botanical Garden: the long-tongued Bombus hortorum, and the medium-tongued B. pascuorum, and the 5 short-tongued species, Bombus hypnorum, Bombus lapidarius, Bombus terrestris, Bombus lucorum, and Bombus pratorum. Bumblebees were observed so that their choice of food within the botanical family could be determined. The shape and colour choice of the flower was particularly noted. Bumblebees showed the highest degree of preference for the Lamiaceae family. The Boraginaceae family was also used by all of the recorded species. Bumblebees found pink and purple, lipped, capitular/globular, and saucer-shaped flowers to be most attractive. The individual species of bumblebees showed different preferences, which may be explained by the differences in their morphology. However, bumblebee flower preference and selection seems to be more complex and requires further, detailed research.

Keywords: bumblebees, flowers, food preferences, entomogamic classes, colour.

\section{INTRODUCTION}

The attractiveness of flowers for pollinators, in particular for bees, has been in an evolutionary formation process for over 100 million years. A flower lures bumblebees with its shape, colour and odour. Bee morphology, particularly the length of the tongue, corresponds to the physical details of the flower (Szafer, 1969).

In our geographical region, the longest tongued bees are the bumblebees of the Bombus spp. Like every bee in its developing process, the bumblebee is entirely dependent on flower food. The short-tongued and long-tongued bumblebees are among the approximately 30 Polish species of this insects. During foraging, each of these species focuses its efforts on acquiring food from flowers. The shape and length of the flower tube is correlated with the length of the tongue (Inouye, 1980). It means, that particular species may vary in their flower preferences. Such variation may be linked to the morphology, and method of foraging flowers (Brodie, 1996) as well as flower colour (Gumbert, 2000).

The short-tongued bumblebees, like Bombus terrestris, which have less specialized diets and are able to exploit the broad range of food resources, remain abundant and common (Goulson et al., 2004). A palynological feces analysis of Bombus terrestris revealed pollen belonging to plants from 28 botanical families. Furthermore, for the Bombus terrestris group (4 short-tongued species), plants from 70 botanical families are mentioned (Dylewska, 1996). In contrast, the long-tongued bumblebees are the most vulnerable to extinction (Gouls on, 2005). The reason might be: a more narrower foodplant specialization, or the fact that they emerge late in the season (Ruszkowski, 
1998), and their longer colony cycle might expose them to food losses in late summer (Williams et al., 2009). According to Goulson (2005), the bumblebee which remains abundant and ubiquitous, and has one of the longest tongues from among all the European species, is the Bombus hortorum. Perhaps it is less specialized in its diet.

All Polish species of bumblebees are protected, but most of them are in the Red List of Threatened Animals in Polnad. Effective protection requires specific actions which can be taken only with essential knowledge of bumblebee ecology.

The objective of this study was to determine the food preferences of the Wrocław Botanical Garden bumblebees. The presence of 7 species was revealed, of which 2 belong to the long- and mediumtongued, and the rest are short-tongued bumblebee species (Tab. 1). Furthermore, the attractiveness of flowers from particular botanical families was analyzed, taking into consideration the shape and colour of the flowers.

\section{MATERIALS AND METHODS}

The study was conducted in the Wrocław Botanical Garden in the spring season of 2009 and 2011 as well as the summer season of 2010 and 2011.

The Wrocław Botanical Garden is one of the exemplary landmarks of Lower Silesia. It falls second only to the oldest Botanical Garden in Poland - which is in Kraków. It is located at the north side of the Cathedral of St. John the Baptist, and the Church of the Holy Cross, partially within historic Ostrów Tumski (Cathedral Island), about $2 \mathrm{~km}$ from Market Square. The beginning of the Wrocław Botanical Garden dates back to 1811. The Garden has an area of 7.4 ha. There are more than 11500 species and varieties of ground and greenhouse plants in the Garden.

Observations were carried out at least three times a week, between 11.00 and 17.00 , when the weather was favorable for bee activity. The bumblebees were observed on foraged plant species. Individual bee species were counted and recorded on the identified foraging plant area. The visited plants and their botanical family membership were recorded To asses the number of botanical families most often visited by each bumblebee species, it was decided that to be counted, a plant family had to have at least $5 \%$ of the total bee visits. In addition, according to entomogamic classes (Szafer, 1969), the shape of the flower was defined. The color was defined by the observer (white, yellow, orange, pink, violet, red, blue).

Bumblebees were determined by the "live method" (Kowalczyk et al., 2004) based on the "Colored key to the recognition of national bumblebee species in field conditions" (Dylewska et al., 2000). The B. terrestris and B. lucorum bees were counted together, since distinguishing them in the field is unreliable. Morphological and phenological characteristics of tagged bumblebee species were compiled according to reference data (Tab. 1).

Table 1 .

Morphologic characteristics and phenology of bumblebees

\begin{tabular}{|c|c|c|c|c|c|}
\hline & \multicolumn{3}{|c|}{$\begin{array}{c}\text { Body length } \\
\text { (Dylewska, 1996) }\end{array}$} & \multirow{2}{*}{$\begin{array}{c}\text { Tongue length } \\
\text { (Ruszkowski, 1998) }\end{array}$} & \multirow{2}{*}{$\begin{array}{c}\text { Emerging spring } \\
\text { periods of queens } \\
\text { (Rus z kow s k i } \\
\text { et al., 1998) }\end{array}$} \\
\hline & q & P & 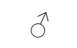 & & \\
\hline B. pascuorum & $15-18$ & $9-15$ & $12-14$ & Medium & medium late \\
\hline B. hypnorum & $17-23$ & $10-15$ & $14-16$ & Short & early \\
\hline B. lapidarius & $18-22$ & $11-17$ & $11-15$ & Short & medium late \\
\hline \multirow{2}{*}{ B. terrestris/lucorum } & $20-23$ & $11-17$ & $14-16$ & \multirow{2}{*}{ Short } & \multirow{2}{*}{ early } \\
\hline & $18-21$ & $9-16$ & $14-16$ & & \\
\hline B. pratorum & $15-17$ & $9-14$ & $11-13$ & Short & early \\
\hline B. hortorum & $17-22$ & $11-16$ & $13-15$ & Long & medium late \\
\hline
\end{tabular}




\section{RESULTS}

During the research period, 7 bumblebees species were observed: Bombus pascuorum, B. hypnorum, B. lapidarius, B. terrestris/lucorum, $B$. pratorum, and B. hortorum. The total number of bees was 1931 . The dominating species was B. terrestris/lucorum - 59\%, then B. pascuorum - $14 \%$, and B. lapidarius $-11 \%$. The remaining three species did not exceed $10 \%$ (Tab. 2).

For the entire observation period, the dominating bumblebees, B. terrestris/ lucorum, foraged on 133 flowering plant species belonging to 32 botanical families. B. pascuorum foraged on 88 plant species from 29 families, and B. lapidarius foraged on 52 species from 22 botanical families. The rest of the studied bumblebees foraged on fewer than 50 plant species belonging to, at most, 19 botanical families (Tab. 2).

For all bumblebee species, the most attractive botanical family was Lamiaceae (Fig. 1). For B. pratorum and B. pascuorum, plants of the Lamiaceae family accounted for a 30\% range of food. For other bee species, plants of the Lamiaceae family accounted for a $15-25 \%$ range of food. B. terrestris/lucorum and B. pratorum often visited plants of the Asteraceae family, but for B. hypnorum the Rosaceae family was attractive. In addition, only the Boraginaceae family was preferred by all bumblebee species at a level above $5 \%$. It is clear that the broadest spectrum of 8 botanical families were preferred by B. lapidarius, 7 families were preferred by
B. hortorum and B. terrestris/lucorum, and 5 families were preferred by B. pascuorum. B. pratorum had the narrowest spectrum 3 botanical families (Tab. 2 ).

The nutrient spectrum of $B$. hortorum was distinguished from that of other bee species by the presence of plants from the Rannunculaceae and Asparagaceae families. For B. terrestris/lucorum, this unique family was Amarylidaceae, and for B. lapidarius - Alliaceae (Fig. 1). Flower preferences based on entomogamic classes, highlighted the shape choice: lipped, capitular/globular, and saucershaped. This preference applies in particular to B. terrestris-lucorum and $B$. hortorum, which also preferred bellshaped flowers to the same extent. Other bumblebee species preferred, in various degrees, certain shapes of flowers. For B. pascuorum, the most attractive was the lipped shape, foraged with a frequency of once every three visits. Three bumblebee species foraged the capitular/globular flowers at the same frequency that they foraged the lipped flowers. Saucer-shaped flowers was preferred by B. lapidarius and $B$. hypnorum. The least frequently visited flowers by bumblebees were: funnelshaped, trumpet-shaped and pea-shaped (Fig. 2).

Pink and violet colors were the most attractive for all bumblebee species. On the average, one out of every two visited flowers were pink or violet. Nevertheless $B$. lapidarius preferred yellow flowers, and B. pratorum - blue

Table 2 .

The number of individuals in particular species of bumblebees

\begin{tabular}{||l|c|c|c|c|c||}
\hline & $\begin{array}{c}\text { No. of } \\
\text { individuals }\end{array}$ & $\begin{array}{c}\text { Share in } \\
\text { the cluster } \\
{[\%]}\end{array}$ & $\begin{array}{c}\text { The no. } \\
\text { of visited } \\
\text { plant } \\
\text { species }\end{array}$ & $\begin{array}{c}\text { The no. } \\
\text { of visited } \\
\text { botanical } \\
\text { families }\end{array}$ & $\begin{array}{c}\text { The no. } \\
\text { of visited } \\
\text { botanical } \\
\text { families } \\
(>5 \%)\end{array}$ \\
\hline B. pascuorum & 264 & 14 & 88 & 29 & 5 \\
\hline B. hypnorum & 112 & 6 & 41 & 19 & 4 \\
\hline B. lapidarius & 218 & 11 & 52 & 22 & 8 \\
\hline B. terrestris/lucorum & 1134 & 59 & 133 & 32 & 7 \\
\hline B. pratorum & 154 & 8 & 46 & 16 & 3 \\
\hline B. hortorum & 50 & 3 & 24 & 14 & 7 \\
\hline
\end{tabular}



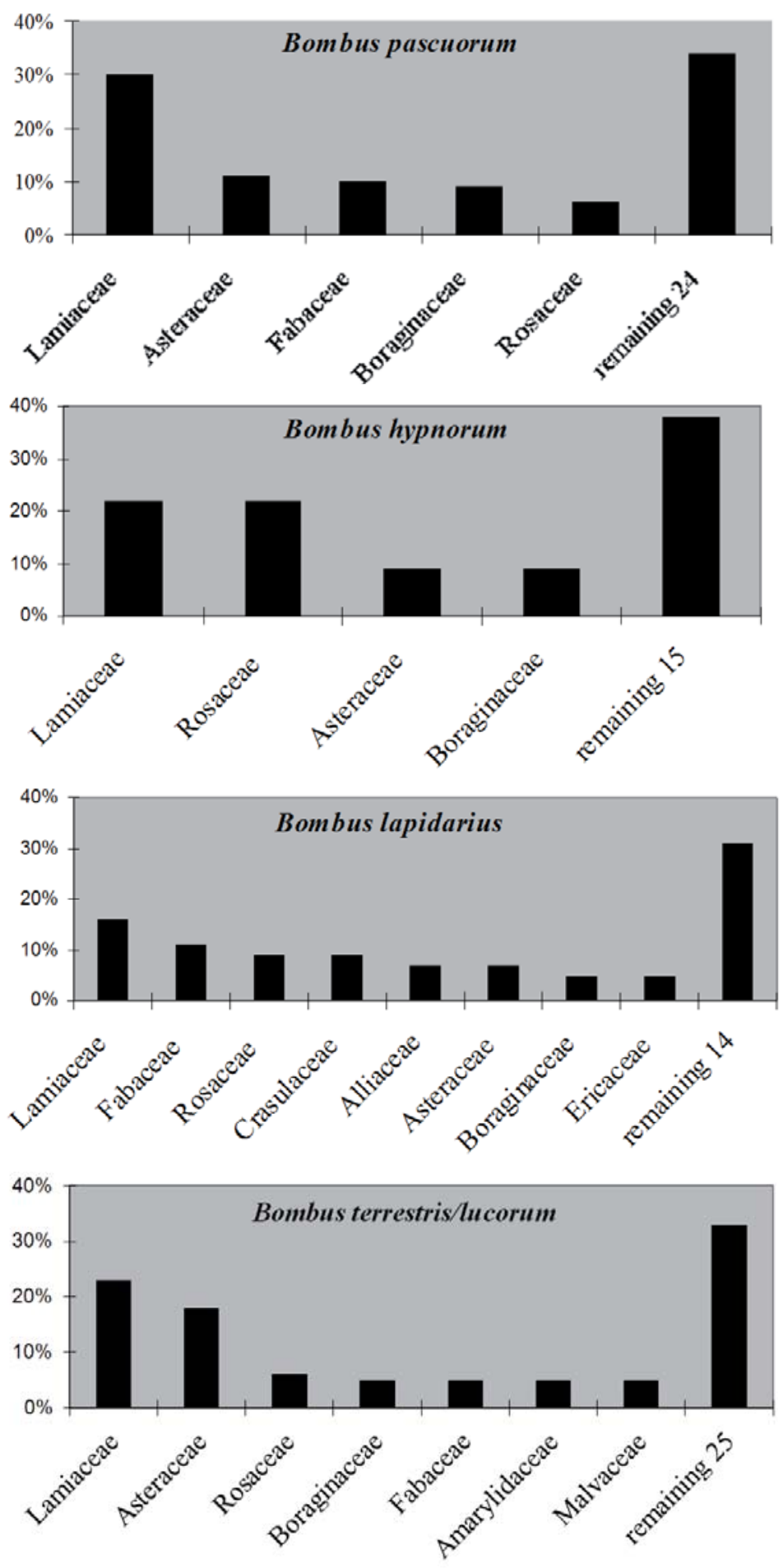

Fig. 1. Bumblebee food preferences within the botanic families. 

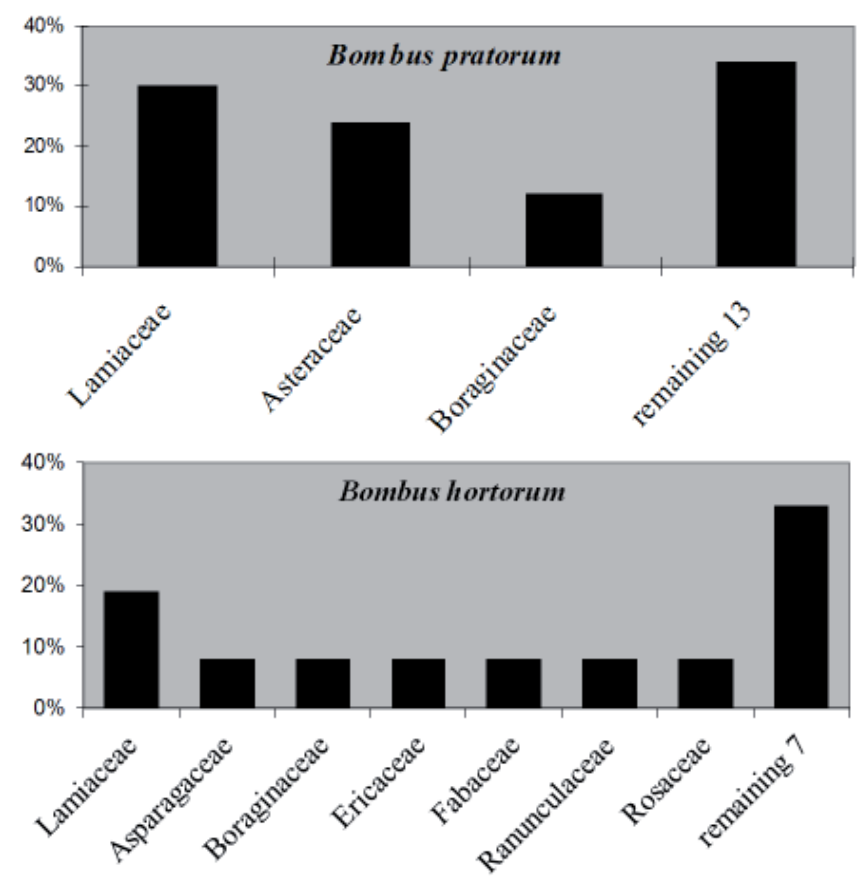

Fig. 1. Countinued. Bumblebee food preferences within the botanic families.

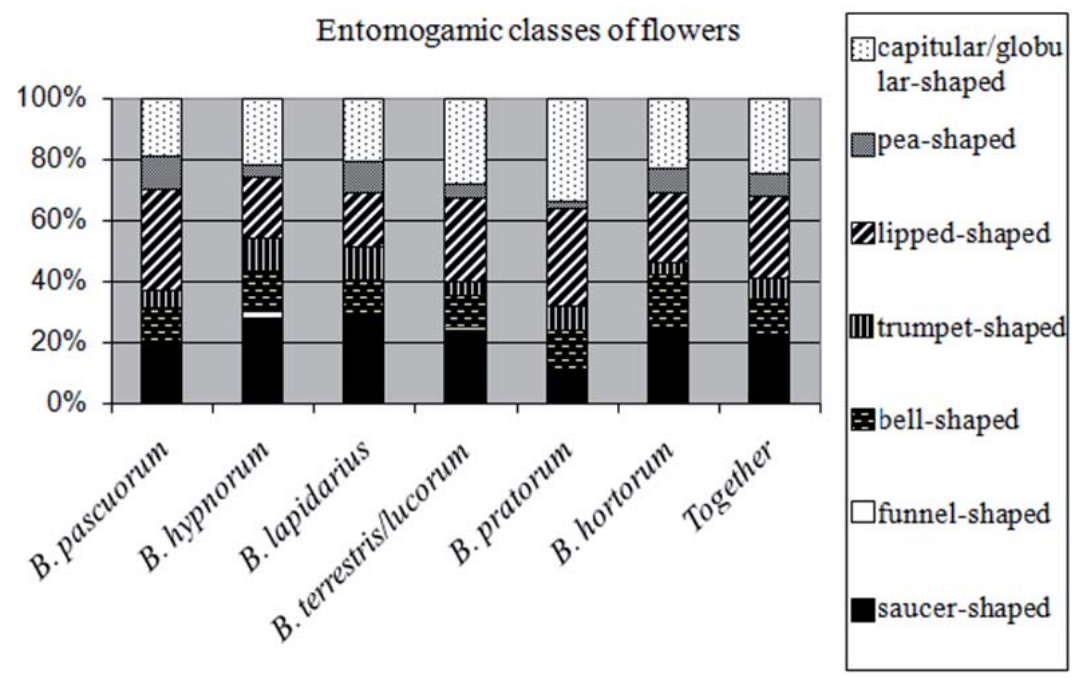

Fig. 2. Bumblebee preferences with regard to the entomogamic classes of flowers.

flowers at approximately $20 \%$. The attractiveness of yellow, blue and white flowers did not exceed the $20 \%$ level for other bumblebee species.
The less attractive colors were red and orange - altogether, visited less than $10 \%$ (Fig. 3). 


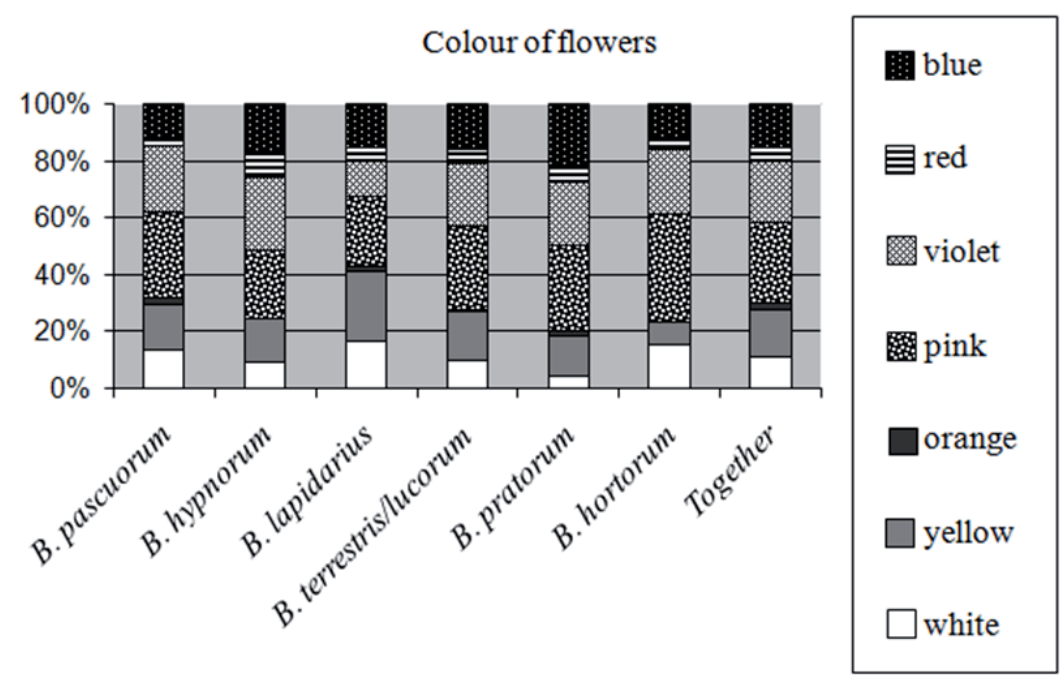

Fig. 3. Bumblebee preferences with regard to flower colours.

\section{DISCUSSION}

According to Pyke (1982), the composition of bumblebee species able to occupy a common habitat, is determined by the tongue length. This phenomenon can be explained by competition for food resources. However, some shorttongued bumblebees frequently occur together. In the Wrocław Botanical Garden 5 bumblebee species are shorttongued. Furthermore, this species forages on the same food resources (Lamiaceae, Asteraceae, Boraginaceae). The bigger the number of individuals of a particular species, the wider the spectrum of visited plant botanical families occurred. It is difficult to say if this result was because it was easier to observe abundant species, or because certain species had the ability to use broad food resources. Perhaps ubiquitous species can forage on a broad range of plant species resources suitable for them, because only the B. terrestris/ lucorum bumblebee and B. lapidarius used such botanical families as Amarylidaceae and Alliaceae. Williams et al. (2009) believed a privileged position was achieved by the larger number of individuals in the colony cycle of those species which emerge early from hibernation. However, amongst short-tongued bumblebees, B. lapidarius starts its annual activity later and achieves greater numbers in the Wrocław Botanical Garden, than B. hypnorum and B. pratorum which emerge earlier.

Long-tongued bumblebees have more specialized diets and thus are more vulnerable to extinction (Williams et al., 2009; Gouls on et al., 2004). Nonetheless, two long-tongued bumblebee species (B. hortorum and B. pascuorum ) as well as 4 short-tongued species belong to the "big six" UK common bumblebee species which are most often found in gardens (Gouls on et al., 2006). B. hortorum, which has one of the longest tongues, is found throughout Poland (Dylewska, 1996; Pawlikowski, 2008). Goulson (2005) claims that $B$. hortorum is less specialized in its diet than other long-tongued species, so dwindling numbers of deep flowers are sufficient to support one long-tongued species but no more. B. hortorum, which had the lowest number of individuals, foraged on a relatively wide range of plant botanical families, including Asparagaceae and Ranunculaceae, which are unattractive for other species. For the medium-tongued bumblebees, B. pascuorum (second in terms of numbers), the plant botanical family spectrum was narrower, with the most attractive being the Labiateae 
family. This bumblebee species more than other bumblebees, foraged more often on Fabaceae family plants. This data confirms the particular B. pascuorum preference for Pea family flowers recorded by Brodie (1996). This author conducted studies on 6 bumblebee species in North-East Scotland, and only B. pascuorum foraged on clover, vicia, and pea flowers.

The bumblebees preferred plants from the Labiateae family in which the plants were found in the open spaces (Brodie, 1996; Goulson et al., 2004) of the Cambridge University Botanical Garden (Comba et al., 1999) as well as the open spaces of allotment gardens (Ahrne, 2008). The results of the studies in the Wrocław Botanical Garden confirmed the bumblebee preference for the Labiatae family. In the Wrocław Botanical Garden, all bumblebee species foraged to the highest degree, on the Labiatae plant family. Gouls on et al. (2004, 2005) state that Fabaceae appears to be the major pollen source for longtongued bumblebees. In the Wrocław Botanical Garden, only B. pascuorum and $B$. lapidarius used the pollen resources from Fabaceae plants. According to Comba et al. (2004), short-tongued bumblebees (B. terrestris, B. lucorum, B. lapidarius, B. pratorum) collected nectar from Asteraceae. Our studies point out that Asteraceae was also a nectar source for medium-tongued B. pascuorum. Gouls on et al. (2004) also noted Scrophulariaceae and Boraginaceae as other nectar sources. In the Wrocław Botanical Garden, the Boraginaceae family was visited as well by all bumblebee species.

But what exactly attracts bumblebees to flowers? From the standpoint of etiology, it is a congenital mechanism, released in response to flower stimuli (Seguin et al., 2008). This object can be colour, size and shape, and odour, or an advertising nutrient contained in the flower- nectar and pollen (Whitney et al., 2008).

The assumption that bees have a preference for colour, especially towards blue, was put forward in the $19^{\text {th }}$ century by Müller. Laboratory experiments in which insects were used to study the possibility of associating different colors with a yield of nectar, showed that bumblebees learn the quickest associations with the purple color (Gumbert, 2000). Another experiment showed that bumblebees, when making a first-time-in-their-life choice between blue and purple, prefer the latter (Raine et al., 2007b). It should also be pointed out, that bees see differently than humans. Von Frisch (1977), in the 19th century, proved that bees cannot see the color red but they see in the ultraviolet, and for them the absorption of light is essential. It is difficult for humans to imagine (Dylewska, 1996). In the Wroclaw Botanical Garden, the observed color preferences within the pink, purple, and blue color agree with the assumptions made by Von Frisch(1997) that bumblebees prefer blue and UV-blue.

The favorite flower form most visited by bumblebees in the Botanical Garden in Wrocław were lip shaped. This shape is closely associated with the construction of flowers in the family Lamiaceae. The second choice was the capitular/ globular shape. This flower shape usually belongs to the Asteraceae family. There are many small, single flowers collected in the bowl or basket which give the capitular/globular shape. Such a flower structure allows bumblebees to freely land, cool their body, and thus, save energy. On the other hand, these flowers require multiple probings to extract nectar. Prior to departure from the flower, the insect usually shivers to warm its body; but shivering is an energetically costly activity. In a series of biochemical transformations, using the fructose bisphosphate enzyme, the insect can also raise its body temperature, using less energy than the shiver. B. lapidarius has the highest activity of this enzyme (Brodie, 1996). Capitular shaped flowers are a characteristic of the Alliaceae family, on which the bumblebees were foraging. Teper (2005), who studied differences in food preferences, used the farmed families of $B$. terrestris and B. lapidarius to draw attention to the predilection of $B$. lapidarius for plants of the genus Allium. Teper 
(2005) saw the possibility of using $B$. lapidarius for pollination of seed crops. In experimental studies on the nutrients choices of bumblebees, concerning flower size, major preferences were not recorded. In the first flight, bumblebees associated the defined size of the flower with the resource of nectar. In later foraging stages, the bumblebees did not choose the same size of flowers. The above information suggests that bumblebees are guieded by odour and colour, rather than a certain flower size (Blarer et al., 2002).

Apart from what attracts insects to a flower, there remains the question of what can repel insects from a flower? Darwin (1891) formulated a theory that insects forage on the flowers of one species as long as they have enough food resources. This means, that guided by instinct only, they strive to reduce the diversity of visited plants. Perhaps during flights from one plant to another, a bumblebee is forced to change and instead follow the fragrance trail left by another bee (Goulson et al., 1998), or short-term memory reduction (1-2 seconds) may play a role (Raine et al., 2007a). The number of botanical families (above $5 \%$ ) most often visited by the different species of bumblebees in the Wrocław Botanical Garden is not proportional to the number of these insects. The reverse situation would explain the observations of the more numerous species. Bumblebee preferences in choosing flowers, although showing some trends in the shape and colour of flowers, appear to be more complex. Therefore, there is a need for further research on bumblebee behaviour.

\section{CONCLUSIONS}

1) Amongst the identified species of bumblebees in the Wroclaw Botanical Garden, the majority were short-tongued bumblebees. The Bombus pascuorum species belonging to the medium-tongued bumblebees, came in second. Bombus hortorum representing the long-tongued species, occurred in the lowest numbers.

2) The number in the particular bumblebee species was correlated with the range of visited botanical families.
3) All species of bumblebees, regardless of the tongue length, found the following to be most attractive: the Lamiaceae family, pink and purple colour and lipped, capitular/ globular and saucer-shaped flowers.

\section{REFERENCES.}

Ahrne K. (2008) - Local Management and Landscape Effect on Diversity of Bees, Wasps and Birds in Urban Green Area, [online] http:// pub.epsilon.slu.se/1766/1/Kappan.pdf.

Blarer A., Keasar T., Shmida A. (2002)

- Possible mechanisms for the Formation of Flower Size Preferences by Foraging Bumblebees. Ethology, 108: 341-351.

Brodie L. (1996) - Bumblebee Foraging Preferences: Differences between Species and indywiduals, [online] http://www.bumblebee. org/thesis/thesis.pdf.

Comba L., Corbet S. A., Hunt L., Warren B. (1999) - Flowers Nectar and Insect Visit: Evaluating British Plant species for pollinator Friendly gardens. Ann. Botany, 83: 369-383.

Darwin C. (1891) - The effects of cross and self fertilisation in the vegetable kingdom, The Complete Work of Charles Darwin Online, [online] Darwin-online.org.uk.

Dylewska M. (1996) - Nasze Trzmiele. Ośrodek Doradztwa Rolniczego, APW, Karniowice, pp. 256.

Dylewska M., Flaga S. (2000) - Barwny klucz do rozpoznawania w warunkach polowych krajowych gatunków trzmieli. Polski Klub Ekologiczny, Kraków, pp. 80.

Frisch K. von (1977) - Aus dem Leben der Bienen, Springer Verlag, Berlin, pp. 194.

Goulson D., Hawson S. A., Stout J. C. (1998) - Foraging bumblebees avoid flowers already visited by specific or by other bumblebee species. Anim. Behav., 55: 199-206.

Goulson D., Darvill B. (2004) - Niche overlap and diet breath in bumblebees; are rare species more specialized in their choice of flowers? Apidologie, 35: 55-63.

Goulson D. (2005) - Causes of rarity in bumblebees. Biol. conserv., 125: 1-8. 
Goulson D., Hanley M. E., Darvill B., Ellis J. S. (2006) - Biotope associations and decline of bumblebees (Bombus spp.). J. Insect Conserv., 10: 95-103.

Gumbert A. (2000) - Color choices by bumble bees (Bombus terrestris): innate preferences and generalization after lerning. Behav. Ecol. Sociobiol., 48: 36-43.

Inouye D. W. (1980) - The effect of proboscis and corolla tube lengths on patterns and rates of flower visitation by bumblebees. Oecologia, 45: 197-201.

Kowalczyk J. K., Szczepko K., Kurzac T., Pawlikowski T. (2004) Pszczoły (Hymenoptera, Apoidea) Ogrodu Botanicznego w Łodzi, [in:] Fauna miast Europy Środkowej 21. wieku, red. Barczak T., Indykiewicz P., Wyd. LOGO Bydgoszcz, pp. 67-83.

Pawlikowski T. (2008) - A distribution Atlas of Bumblebees in Poland (Hymenoptera: Apoidea: Bombini). Wyd. Nauk. Uniwersytetu Mikołaja Kopernika, Toruń, pp. 103.

Pyke G. H. (1982) - Local geographic distributions of bumblebees near Crested Butte, Colorado: competition and community structure. Ecology, 63: 555-573.

Raine E. N., Chittka L. (2007a) - Flower Constancy and Memory Dynamics in Bumblebees (Hymenoptera: Apidae: Bombus). Entomol. Gene., 29(2-4): 179-199.

Raine N. E., Chittka L. (2007b) - The Adaptive significance of Sensory Bias in Foraging Context: Floral Colour Preferences in the Bumblebee Bombus terrestris. PLoS ONE, 2(6): e556.
Ruszkowski A. (1998) - Rośliny wskaźnikowe dla trzmieli (Bombus Latr.) krótkojęzyczkowych; długo- i średniojęzyczkowych. Pszczeln. Zesz. Nauk. Rok XLII, 1: 321-332; 333-343

Ruszkowski A., Biliński M., Gosek J., Kaczmarska K., Zadura M. (1998) Terminy pojawu trzmieli (Bombus Latr.) wiosną i możliwość ich prognozowania. Pszczeln. Zesz. Nauk. Rok XLII, 1: 345-353.

Seguin F. R., Plowright C. M. S. (2008) - Assessment of patern preferences by flowernaive bumblebees. Apidologie, 39: 215-224.

Szafer W. (1969) - Kwiaty i zwierzęta, PWN, Warszawa, pp. 386.

Teper D. (2005) - Comparison of food plants of Bombus terrestris L. and Bombus lapidarius L. based on pollen analysis of their pollen loads. J. Apic. Sci., 49(2): (43-50).

Teper D. (2006) - Food plants of Bombus terrestris L. as determined by pollen analysis of feaces. J. Apic. Sci., 50(2): 101-108.

Whithney H. M., Dyer A., Chittka L., Rands S. A., Glover B. J. (2008) The interaction of temperature and sucrose concentration on foraging preferences in bumblebees. Naturwissenschaften, 95: 845-85.

Williams P. H., Osborne J. L. (2009) Bumblebee vulnerability and conservation world-wide. Apidologie, 40: 367-387. 


\title{
TRZMIELE (Bombus spp.) W OGRODZIE BOTANICZNYM WE WROCLAWIU I ICH POWIĄZANIA Z MORFOLOGIĄ OBLATYWANYCH KWIATÓW
}

\author{
Sikora A., Kelm M.
}

$\mathrm{St} r$ e s z c z e n i e

Trzmiele (Bombus spp.) morfologicznie różnią się od siebie długością języczka. W faunie Ogrodu Botanicznego stwierdzono występowanie 7 gatunków trzmieli, a wśród nich długojęzyczkowego Bombus hortorum i średniojęzyczkowego B. pascuorum, oraz 5 gatunków krótkojęzyczkowych: Bombus hypnorum, Bombus lapidarius, Bombus terrestris, Bombus lucorum, Bombus pratorum. Obserwowano zachowania trzmieli przy wyborze pokarmu, aby określić ich preferencję w obrębie rodzin botanicznych, a szczególnie w wyborze kształtu i barwy kwiatu. Trzmiele wykazywały w najwyższym stopniu upodobania do rodziny Lamiaceae, ponadto wszystkie korzystały z roślin Boraginaceae. Kwiaty, które przyciągały trzmiele najczęściej miały barwę różową i fioletową oraz kształt typu wargowego, główkowatego/koszyczkowatego i talerzykowatego. Poszczególne gatunki trzmieli wykazywały odmienne upodobania, co można próbować tłumaczyć różnicami w ich morfologii. Jednak preferencje w wyborze kwiatu przez trzmiele wydają się na tyle złożone, że wymagają dalszych i bardziej szczegółowych badań.

Słowa kluczowe: trzmiele, kwiaty, preferencje pokarmowe, klasy entomogamiczne, kolor. 